\title{
Research on Formaldehyde Release Rate of Car mats
}

\author{
Song Zhao ${ }^{\text {a, }}$ Yanling Wang, Lei Wang, Yanan Lu, Xueli Han, Jin Liu* \\ Hebei Academy of Product Quality Supervision and Inspection, Shijiazhuang 050200, Hebei China \\ a930575554@qq.com
}

\begin{abstract}
The environmental test cabin method was used to simulate the actual use environment of car mats to collect test gas, The formaldehyde content in the collected gas was measured by ultraviolet spectrophotometer, and the formaldehyde release rate was calculated. The results indicated that formaldehyde was released in all 30 batches of samples at a rate ranging from 0.02 to $0.13 \mathrm{mg} / \mathrm{m} 2(\mathrm{~m} 2 \cdot \mathrm{h})$.
\end{abstract}

Keywords: Car mats, formaldehyde release rate, environmental test cabin, ultraviolet spectrophotometer

\section{Introduction}

As people's living standards are getting higher and higher, the number of cars in China is increasing year by year, and cars have gradually become the means of transportation for people's daily travel[1]. When people pay attention to the convenience of travel, they often ignore the serious consequences of environmental pollution in small cars, which poses a serious health threat to drivers and passengers[2]. There are many reasons for the primary pollution of the automotive interior environment. As an important automotive interior product, the quality of the automotive floor mat directly affects the automotive interior environment.

Inferior floor mats emit toxic and harmful gases, which is one of the main causes of air pollution in the vehicle. At present, the VOC detection method for the air in the vehicle has become mature[3]. GB/T 27630-2011 guidelines for air quality evaluation in passenger cars also set corresponding requirements for the limits of eight volatile organic compounds such as benzene in the air in the vehicle, but for the car floor mats, There is no corresponding national standard. Formaldehyde is a colorless and soluble gas with strong pungent smell, which mainly comes from the inferior components and adhesives of automobile footmats. Formaldehyde can enter the human body through the respiratory tract. It has the characteristics of long-term, latent and hidden. It is a protoplasm poison. When combined with protein, it will lead to the imbalance of nervous system and immune system. It is also a carcinogen. Excessive inhalation of formaldehyde will produce adverse reactions such as fainting, fatigue, muscle weakness, syncope, and even death[4-5].

Hebei Province is a large province for the production of automobile floor mats. The production is mainly concentrated in Xinle City of Shijiazhuang and Nangong city of Xingtai. It is mainly small enterprises and even family workshops. The product quality is uneven. The problems of product quality and safety are reflected in the use safety and air pollution in the car. In recent years, the relevant national departments have not conducted supervision and random inspection on the automobile foot pad products, and the product quality situation of the industry is not clear. Therefore, it is urgent to study and monitor the product quality of automobile foot pad products.

In this study, the environmental test chamber is used to simulate the actual use environment of automobile foot pad products, collect the test gas, test the formaldehyde content in the collected gas by UV-Vis spectrophotometer, calculate the formaldehyde release rate, and discuss the use risk of automobile foot pad products.

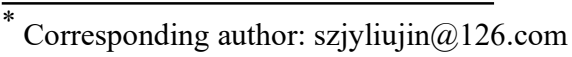




\section{Experimental}

\subsection{Materials}

In this study, the environmental test chamber is used to simulate the actual use environment of automobile foot pad products, collect the test gas, test the formaldehyde content in the collected gas by UV-Vis spectrophotometer, calculate the formaldehyde release rate, and discuss the use risk of automobile foot pad products. Car floor mats are common in the market, including latex type, silk ring type and large surrounding type (Fig. 1). The samples are purchased from the auto fittings (supplies) business premises registered in Hebei Province with the business license, and the scale of the business premises is small. The sample unit is set, and the sampling quantity is 1 set / batch, a total of 30 batches. Among them, there are 15 batches of emulsion type, 11 batches of wire loop shape and 4 batches of large enclosure
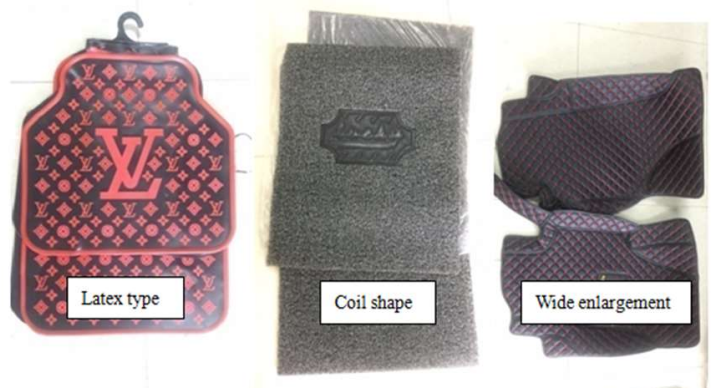

Figure 1 Sample category

\subsection{Experimental method}

Prepare the sample with the material / cabin load ratio of $0.4 \mathrm{~cm} 2 / \mathrm{m} 3$, cut the surface artificially and cover the ground with aluminum foil. The sample shall be built into the environmental test chamber for testing $1 \mathrm{~h}$ after preparation. Place the sample in the middle of the environmental test chamber (air temperature $60{ }^{\circ} \mathrm{C}$, relative humidity $5 \%$, air exchange rate 1 time $/ \mathrm{h}$, air velocity on the sample surface $0.2 \mathrm{~m} / \mathrm{s}$ ), the emission surface is horizontal and upward, so that the air flow passes through the time surface evenly, and quickly close the cabin door of the environmental test chamber to start the test. The time of putting into the environmental test chamber is 0 , and the air in the chamber is sampled and analyzed after 24 hours of balance.

Put $5 \mathrm{ml}$ absorption solution into the bubble absorption tube, sample at the flow rate of $0.51 / \mathrm{min}$, and the gas production volume is $10 \mathrm{~L}$. Transfer all the sample solution into a $10 \mathrm{ml}$ colorimetric tube, wash the absorption tube with a small amount of absorption solution, combine to make the total volume of $5 \mathrm{ml}$, add $0.4 \mathrm{ml}$ ammonium ferric sulfate solution, shake well and place for $15 \mathrm{~min}$. At the wavelength of $630 \mathrm{~nm}$, the absorbance of each tube solution was measured with a $1 \mathrm{~cm}$ cuvette and water as the reference. At the same time, $5 \mathrm{ml}$ of unsampled absorption solution was used as blank control. Determine the formaldehyde content according to the standard curve.

Formaldehyde emission $(\mathrm{Ci}), \mathrm{C}_{\mathrm{i}}=\frac{\left(\mathrm{m}-\mathrm{m}_{0}\right) \times 1000}{1000 \times \mathrm{V}_{0}}$

Formaldehyde concentration in sample under standard state(Csi),mg/m3, $\mathrm{C}_{\mathrm{si}}=\mathrm{C}_{\mathrm{i}} \times \frac{101.3}{P} \times \frac{\mathrm{t}+273}{273}$

Formaldehyde release rate $(\mathrm{EFI}), \mathrm{mg} /(\mathrm{m} 2 * \mathrm{~h})$, $\mathrm{EFi}=\frac{\mathrm{C}_{\mathrm{si}} \times V \times A C H}{\mathrm{~S}}$

Sample volume(V0), L

Working pressure of environmental test chamber (P), $\mathrm{kPa}$ Ambient cabin temperature $(\mathrm{t}),{ }^{\circ} \mathrm{C}$

Sample preparation area $(\mathrm{S}), \mathrm{m} 2$

Sample preparation area and volume in environmental chamber(V), m3

Ventilation rate of environmental chamber(ACH),times/h

Formaldehyde quality of sample blank $(\mathrm{m} 0), \mu \mathrm{g}$

Formaldehyde mass of sample solution(m), $\mu \mathrm{g}$ 


\section{Results and Discussion}

Table 1 is the statistics of formaldehyde emission rate test results of 30 batches of car foot mats.

Table 1 Test results of formaldehyde release rate

\begin{tabular}{|c|c|c|c|c|}
\hline \multicolumn{2}{|c|}{ Name } & $\begin{array}{c}\text { Latex } \\
\text { type }\end{array}$ & $\begin{array}{c}\text { Wide } \\
\text { enlargement }\end{array}$ & $\begin{array}{c}\text { Coil } \\
\text { shape }\end{array}$ \\
\hline \multirow{2}{*}{$\begin{array}{c}\text { Result } \\
\text { rangemg } /\left(\mathrm{m}^{2} \cdot \mathrm{h}\right)\end{array}$} & $\begin{array}{c}\text { Measured } \\
\text { value }\end{array}$ & $\begin{array}{c}0.02 \sim \\
0.11\end{array}$ & $0.05 \sim 0.12$ & $\begin{array}{c}0.03 \sim \\
0.13\end{array}$ \\
\cline { 2 - 5 } & $\begin{array}{c}\text { average } \\
\text { value }\end{array}$ & 0.05 & 0.08 & 0.06 \\
\hline \multicolumn{2}{|c|}{ Total averagemg $/\left(\mathrm{m}^{2} \cdot \mathrm{h}\right)$} & \multicolumn{3}{|c|}{06} \\
\hline
\end{tabular}

It can be seen from table 1 that the detected value range of formaldehyde release rate of the sample is $0.02 \sim 0.13 \mathrm{mg} /(\mathrm{m} 2 \cdot \mathrm{h})$, and the average value is 0.06 $\mathrm{mg} /(\mathrm{m} 2 \cdot \mathrm{h})$. The formaldehyde release rate of different types of automobile footrest samples is slightly different. Among them, the formaldehyde release rate of large surrounding samples is the highest, reaching0.08 $\mathrm{mg} /(\mathrm{m} 2 \cdot \mathrm{h})$. The formaldehyde release rate of latex samples is lower than the average value, which is 0.05 $\mathrm{mg} /(\mathrm{m} 2 \cdot \mathrm{h})$.

Table 2 Body effects of different formaldehyde concentrations

\begin{tabular}{|c|c|}
\hline $\begin{array}{c}\text { concentration } \\
\left(\mathrm{mg} / \mathrm{m}^{3}\right)\end{array}$ & effect \\
\hline 0.05 & EEG changes \\
\hline 0.06 & Eye stimulation threshold \\
\hline $0.06 \sim 0.22$ & Olfactory stimulation threshold \\
\hline 0.12 & $\begin{array}{c}\text { Upper respiratory tract } \\
\text { irritation threshold }\end{array}$ \\
\hline 0.16 & Increase in respiratory diseases \\
\hline 1.0 & tissue damage \\
\hline 6.0 & Pulmonary irritation \\
\hline 60.0 & pulmonary edema \\
\hline 120.0 & death \\
\hline
\end{tabular}

As we all know, formaldehyde has a great impact on human health. According to the data given in the Application Manual of national environmental health standards (Table 2) ${ }^{[4]}$, formaldehyde concentration exceeding $0.05\left(\mathrm{mg} / \mathrm{m}^{3}\right)$ can cause harm to human body. According to the actual measurement, the interior space of an ordinary class B car is $3.5 \mathrm{~m} 3$, the service area of car foot pad is $1.5 \mathrm{~m}^{2}$, and the car is exposed to the sun for 6 hours, The concentration range of formaldehyde in the vehicle caused by the test sample alone is $0.05 \sim 0.33 \mathrm{mg}$ $/ \mathrm{m}^{3}$, which can cause harm to human body (Table 3 ).
Table 3 Calculated formaldehyde concentration in the vehicle after exposure for 6 hours

\begin{tabular}{|c|c|c|c|c|c|}
\hline $\begin{array}{c}\text { Serial } \\
\text { number }\end{array}$ & category & $\begin{array}{l}\text { Formaldehyde } \\
\text { concentration }( \\
\left.\mathrm{mg} / \mathrm{m}^{3}\right)\end{array}$ & $\begin{array}{c}\text { Serial } \\
\text { number }\end{array}$ & category & $\begin{array}{c}\begin{array}{c}\text { Formalde } \\
\text { hyde } \\
\text { concentrat } \\
\text { ion }(\mathrm{mg} / \mathrm{m} \\
\left.{ }^{3}\right)\end{array} \\
\end{array}$ \\
\hline 1 & $\begin{array}{l}\text { Latex } \\
\text { type }\end{array}$ & 0.23 & 16 & $\begin{array}{c}\text { Wide } \\
\text { enlargem } \\
\text { ent }\end{array}$ & 0.31 \\
\hline 2 & $\begin{array}{l}\text { Latex } \\
\text { type }\end{array}$ & 0.10 & 17 & $\begin{array}{c}\text { Wide } \\
\text { enlargem } \\
\text { ent }\end{array}$ & 0.23 \\
\hline 3 & $\begin{array}{l}\text { Latex } \\
\text { type }\end{array}$ & 0.05 & 18 & $\begin{array}{c}\text { Wide } \\
\text { enlargem } \\
\text { ent }\end{array}$ & 0.13 \\
\hline 4 & $\begin{array}{l}\text { Latex } \\
\text { type }\end{array}$ & 0.10 & 19 & $\begin{array}{c}\text { Wide } \\
\text { enlargem } \\
\text { ent }\end{array}$ & 0.21 \\
\hline 5 & $\begin{array}{c}\begin{array}{c}\text { Latex } \\
\text { type }\end{array} \\
\end{array}$ & 0.26 & 20 & $\begin{array}{c}\text { Coil } \\
\text { shape }\end{array}$ & 0.15 \\
\hline 6 & $\begin{array}{l}\text { Latex } \\
\text { type }\end{array}$ & 0.15 & 21 & $\begin{array}{c}\text { Coil } \\
\text { shape }\end{array}$ & 0.21 \\
\hline 7 & $\begin{array}{c}\text { Latex } \\
\text { type }\end{array}$ & 0.08 & 22 & $\begin{array}{c}\text { Coil } \\
\text { shape }\end{array}$ & 0.13 \\
\hline 8 & $\begin{array}{l}\text { Latex } \\
\text { type }\end{array}$ & 0.08 & 23 & $\begin{array}{c}\text { Coil } \\
\text { shape }\end{array}$ & 0.15 \\
\hline 9 & $\begin{array}{c}\text { Latex } \\
\text { type }\end{array}$ & 0.08 & 24 & $\begin{array}{c}\text { Coil } \\
\text { shape }\end{array}$ & 0.13 \\
\hline 10 & $\begin{array}{c}\text { Latex } \\
\text { type }\end{array}$ & 0.15 & 25 & $\begin{array}{c}\text { Coil } \\
\text { shape }\end{array}$ & 0.08 \\
\hline 11 & $\begin{array}{l}\text { Latex } \\
\text { type }\end{array}$ & 0.21 & 26 & $\begin{array}{c}\text { Coil } \\
\text { shape }\end{array}$ & 0.10 \\
\hline 12 & $\begin{array}{l}\text { Latex } \\
\text { type }\end{array}$ & 0.05 & 27 & $\begin{array}{c}\text { Coil } \\
\text { shape }\end{array}$ & 0.13 \\
\hline 13 & $\begin{array}{c}\text { Latex } \\
\text { type }\end{array}$ & 0.13 & 28 & $\begin{array}{c}\text { Coil } \\
\text { shape }\end{array}$ & 0.08 \\
\hline 14 & $\begin{array}{l}\text { Latex } \\
\text { type }\end{array}$ & 0.13 & 29 & $\begin{array}{c}\text { Coil } \\
\text { shape }\end{array}$ & 0.33 \\
\hline 15 & $\begin{array}{l}\text { Latex } \\
\text { type }\end{array}$ & 0.28 & 30 & $\begin{array}{c}\text { Coil } \\
\text { shape }\end{array}$ & 0.08 \\
\hline
\end{tabular}

The sources of formaldehyde in automobile floor mats are complex, mainly caused by poor materials, processing solvents and adhesives. The formaldehyde emission rate of latex type automobile foot pad is low, which is related to its material and processing technology. Latex type automobile foot mats are made of a single material, and most products are made of integrated injection molding or pouring molding. High quality latex materials will not add processing additives containing formaldehyde in the processing process, and will not involve the use of adhesives. Therefore, the formaldehyde release rate of this type of samples is lower than that of other types. Silk ring and wide enlargement car mats are not made of single material. Coil shape mats are generally composed of bottom layer and silk ring, which are bonded with adhesive; Wide enlargement type foot mats are generally of multi-layer structure, and most of the layers are made of adhesive bonding or sewing. Therefore, the formaldehyde emission rate of these two types of automobile foot mats is high.

\section{Conclusion}

In order to simulate the real use environment of automobile foot pads, this risk monitoring adopts the environmental test chamber method to detect the toxic and harmful gases in automobile foot pads. This inspection method can better restore the real use environment of automobile foot pads, and has no restrictions on the type of samples. The results showed that formaldehyde was released from 30 batches of samples, and the release rate ranged from 0.02 to $0.13 \mathrm{mg} /\left(\mathrm{m}^{2} \cdot \mathrm{h}\right)$. 


\section{References}

1. Hangzhou Ming, Huang shunmin, Weng Wenxiang, Yue Gaodong, Yang pan. Study on volatile organic compounds in automobile floor mats [J]. Chemical management, 2017,(05):196+231.

2. Jia Xiaobo, Liu Rongde, Li Jing. Research and development of PVC special materials for automobile footrest [J]. PVC, 2008(08):21-22+33.

3. Cai Baixue, Luo Yuanyuan, Li Xiaolong, Zhang Li, Wang Hao. Risk assessment based on anti-skid performance of automobile footrest [J]. Journal of Chongqing Jiaotong University (NATURAL SCIENCE EDITION), 2018,37(04):128-132.

4. Zhang Chuanzhen, Zhang Jipeng, Zhao Hong, Shi Jin. Study on the harm of automobile interior pollutants to human health $[\mathrm{J}]$. Journal of Qingdao University (Engineering Technology Edition),2014,29(01):105110.

5. Li Dong, ye Jihong, Li Chaojun, Dai Danfeng. Harm and prevention analysis of environmental pollution in cars [J]. Management observation,2015(13):58$59+62$. 